\title{
Manual therapies for primary chronic headaches: a systematic review of randomized controlled trials
}

\author{
Aleksander Chaibi ${ }^{1,2^{*}}$ and Michael Bjørn Russell ${ }^{1,2}$
}

\begin{abstract}
This is to our knowledge the first systematic review regarding the efficacy of manual therapy randomized clinical trials (RCT) for primary chronic headaches. A comprehensive English literature search on CINHAL, Cochrane, Medline, Ovid and PubMed identified 6 RCTs all investigating chronic tension-type headache (CTTH). One study applied massage therapy and five studies applied physiotherapy. Four studies were considered to be of good methodological quality by the PEDro scale. All studies were pragmatic or used no treatment as a control group, and only two studies avoided co-intervention, which may lead to possible bias and makes interpretation of the results more difficult. The RCTs suggest that massage and physiotherapy are effective treatment options in the management of CTTH. One of the RCTs showed that physiotherapy reduced headache frequency and intensity statistical significant better than usual care by the general practitioner. The efficacy of physiotherapy at post-treatment and at 6 months follow-up equals the efficacy of tricyclic antidepressants. Effect size of physiotherapy was up to 0.62 . Future manual therapy RCTs are requested addressing the efficacy in chronic migraine with and without medication overuse. Future RCTs on headache should adhere to the International Headache Society's guidelines for clinical trials, i.e. frequency as primary end-point, while duration and intensity should be secondary end-point, avoid co-intervention, includes sufficient sample size and follow-up period for at least 6 months.
\end{abstract}

Keywords: Randomized clinical trials; Primary chronic headache; Manual therapies; Massage; Physiotherapy; Chiropractic

\section{Introduction}

Primary chronic headaches i.e. chronic migraine (CM), chronic tension-type headache (CTTH) and chronic cluster headache has significant health, economic and social costs. About 3\% of the general population suffers from chronic headache with female predominance [1]. The International Classification of Headache Disorders III $\beta$ (ICDH-III $\beta$ ) defines CM as $\geq 15$ headache days/month for at least 3 months with features of migraine in $\geq 8$ days/ month, CTTH is defined as on average $\geq 15$ days/month with tension-type headache for at least 3 months, and chronic cluster headache as attacks at least every other day for more than 1 year without remission, or with remissions lasting $<1$ month [2].

\footnotetext{
* Correspondence: aleksander.chaibi@medisin.uio.no

${ }^{1}$ Head and Neck Research Group, Research Centre, Akershus University Hospital, 1478 Lørenskog, Oslo, Norway

${ }^{2}$ Institute of Clinical Medicine, Akershus University Hospital, University of Oslo, 1474 Nordbyhagen, Oslo, Norway
}

About $80 \%$ consult their primary physician for primary chronic headache [3], and pharmacological management is considered first line of treatment. However, the risk is that it may cause overuse of acute headache medication due to frequent headache attacks. $47 \%$ of those with primary chronic headache in the general Norwegian population overused acute headache medication [1,4]. Considering the high use of acute medication, both prophylactic medication and non-pharmacological management should therefore be considered in the management $[5,6]$. Prophylactic medication is used only by $3 \%$ in the general Norwegian population, while $52 \%$ have tried physiotherapy and $28 \%$ have tried chiropractic spinal manipulative therapy [3]. Non-pharmacological management has furthermore the advantage of few and usually minor transient adverse events and no pharmacological interaction/adverse event [7]. 
Previous systematic reviews have focused on RCTs for tension-type headache, migraine and/or cervicogenic headache, but not on efficacy on primary chronic headache [5,6,8-11]. Manual therapy is a physical treatment used by physiotherapists, chiropractors, osteopaths and other practitioners to treat musculoskeletal pain and disability, and includes massage therapy, joint mobilization and manipulation [12].

This is to our knowledge the first systematic review assessing the efficacy of manual therapy randomized controlled trials (RCT) for primary chronic headache using headache frequency as primary end-point and headache duration and intensity as secondary endpoints.

\section{Review \\ Methods}

The English literature search was done on CINHAL, Cochrane, Medline, Ovid and PubMed. Search words were; migraine, chronic migraine, tension-type headache, chronic tension-type headache, cluster headache, chronic cluster headache combined with the words; massage therapy, physiotherapy, spinal mobilization, manipulative therapy, spinal manipulative therapy, osteopathic treatment or chiropractic. We identified studies by a comprehensive computerized search. Relevant reviews were screened for additional relevant RCTs. The selection of articles was performed by the authors. All RCTs written in English using either of the manual therapies for CM, CTTH and/or chronic cluster headache were evaluated. Studies including combined headache types without specific results for CM, CTTH and/or chronic cluster headache were excluded. The review included manual therapy RCTs presenting at least one of the following efficacy parameters; headache frequency, duration and pain intensity for CM, CTTH and/ or chronic cluster headache as recommended by the International Headache Society's clinical trial guidelines $[13,14]$. Headache frequency is a primary end-point, while duration and pain intensity are secondary end-points. Headache diagnoses were preferentially classified according to the criteria of ICHD-III $\beta$ or previous editions [2,15-17]. The methodological quality of the included RCTs was evaluated using the PEDro scale, Table 1 [18]. A RCT was considered to be of high quality if the PEDro score was $\geq 6$ of a maximum score of 10 . The methodological quality of the RCTs was assessed by AC. The PRISMA 2009 checklist was applied for this systematic review. Effect size was calculated when possible. Effect size of 0.2 was regarded as small, 0.5 as medium and 0.8 as large [19].

This systematic review was executed directly based on the ascertained RCTs available and has not been registered as a review protocol.
Table 1 PEDro score "yes" or "no" items

\begin{tabular}{ll}
\hline 1. & Subjects were randomly allocated to groups. \\
\hline 3. & Allocation was concealed. \\
\hline 4. & The groups were similar at baseline regarding the most important \\
\hline $5 . \quad$ & There was blinding of all therapists who administered the therapy. \\
\hline $6 . \quad \begin{array}{l}\text { There was blinding of all assessors who measured at least one } \\
\text { key outcome. }\end{array}$ \\
\hline $7 . \quad \begin{array}{l}\text { Measurements of at least one key outcome were obtained } \\
\text { from more than } 85 \% \text { of the subjects initially allocated to groups. }\end{array}$ \\
\hline 8. $\quad \begin{array}{l}\text { All subjects for whom outcome measurements were available } \\
\text { received the treatment or control condition as allocated, } \\
\text { or where this was not the case, data for at least one key } \\
\text { outcome were analyzed by "intention to treat". }\end{array}$ \\
\hline $\begin{array}{l}\text { The results of between-groups statistical comparisons are } \\
\text { reported for at least one key outcome. }\end{array}$ \\
\hline 10. & $\begin{array}{l}\text { The study provides both point measurements and measurements } \\
\text { of variability for at least one key outcome measure. }\end{array}$ \\
\hline
\end{tabular}

The maximum score is 10 if all 10 items can be replied yes.

\section{Results}

The literature search identified six RCTs that met our inclusion criteria. One study applied massage therapy (MT) and five studies applied physiotherapy (PT) [20-25]. All studies assessed CTTH, while no studies assessed CM or chronic cluster headache.

\section{Methodological quality}

Table 2 shows that the methodological PEDro score of the included RCTs ranged from 1 to 8 points. Four RCTs were considered of good methodological quality, while two RCTs had lower scores.

\section{Randomized controlled trials (RCT)}

Table 3 shows the study population, intervention and efficacy of the six RCTs.

\section{Massage therapy}

A Spanish physiotherapist conducted a 2-armed prospective crossover RCT with pairwise comparisons and blinded outcome measures [20]. The study included participants with CTTH diagnosed by a neurologist. The ICHD-II criteria for CTTH were slightly modified, i.e. pain intensity was defined as $\leq 5$ on a $0-10$ numeric pain rating scale, and the accompanying symptoms photophobia, phonophobia or mild nausea was not allowed [16]. Primary and secondary end-points were not specified. Results are shown in Table 3.

\section{Physiotherapy}

An American 3-armed retrospectively RCT had unblinded outcome measures [21]. The diagnostic criteria were $\geq 25$ headache days/month for $>6$ months without associated 
Table 2 The methodological PEDro score of the included randomized controlled trials (RCTs)

\begin{tabular}{llllllllllll}
\hline & $\mathbf{1}$ & $\mathbf{2}$ & $\mathbf{3}$ & $\mathbf{4}$ & $\mathbf{5}$ & $\mathbf{6}$ & $\mathbf{7}$ & $\mathbf{8}$ & $\mathbf{9}$ & $\mathbf{1 0}$ & PEDro score \\
\hline Toro-Velasco [20] & Yes & Yes & Yes & No & No & Yes & Yes & Yes & Yes & Yes & $8 / 10$ \\
\hline Jay [21] & No & No & No & No & No & No & No & No & Yes & No & $1 / 10$ \\
\hline Demirturk [22] & Yes & Yes & Yes & No & No & No & No & No & Yes & Yes & $5 / 10$ \\
\hline Torelli [23] & Yes & Yes & Yes & No & No & No & Yes & No & Yes & Yes & $6 / 10$ \\
\hline Ettekoven [24] & Yes & Yes & Yes & No & No & Yes & Yes & Yes & Yes & Yes & $8 / 10$ \\
\hline Castien [25] & Yes & Yes & Yes & No & No & No & Yes & Yes & Yes & Yes & $7 / 10$ \\
\hline
\end{tabular}

symptoms nausea, vomiting, photo- and phonophobia, but with tender muscles, i.e. CTTH with pericranial tenderness. Participants with cervicogenic headache or neurological findings were excluded. Primary and secondary end-points were not pre-specified, but headache index, defined here as headache frequency $\times$ severity, was the evaluated end-point.

A Turkish study conducted a 2-armed prospective RCT with unblinded outcome measures [22]. The participants were diagnosed with CTTH according to ICHD-I [15]. Participants with mixed headache, neurological and systemic aliment, or participants whom had received physiotherapy within 6 months prior to the study were excluded. Primary end-points was headache index defined as frequency $\times$ severity.

A Danish study conducted a 2-armed prospective RCT with blinded outcome measures [23]. Participants were diagnosed CTTH by a neurologist according to the criteria of ICHD-I [15]. Participants with other primary headaches, neuralgia, neurological, systemic or psychiatric disorders or medication overuse defined as $>100$ analgesic tablets or $>2$ doses of triptans and ergotamine per month were excluded. The primary end-point was headache frequency, and the secondary end-points were headache duration and intensity. The results shown in Table 3 were not influenced by pericranial muscles tenderness.

A Dutch study conducted a 2-armed prospective, multicentre RCT with blinded outcome measures [24]. Participants were diagnosed with CTTH by a physician according to ICHD-I [15]. Participants with multiple headache types or those whom had received physiotherapy within the last 6 months were excluded. Primary end-points were headache frequency while duration and intensity were secondary end-points.

The $2^{\text {nd }}$ Dutch study conducted a 2 -armed prospective pragmatic, multicentre RCT with self-reported primary and secondary end-points, i.e. headache frequency, duration and intensity [25]. Participants were diagnosed by a physician according to the criteria of ICHD-II [16]. Participants with rheumatoid arthritis, suspected malignancy, pregnancy, non-Dutch speaking, those whom had received physiotherapy within the last 2 months, triptan, ergotamine or opiods users were excluded.

\section{Discussion}

The current systematic review evaluating the efficacy of manual therapy in RCTs for primary chronic headaches only identified RCTs treating CTTH. Thus, the efficacy of $\mathrm{CM}$ and chronic cluster headache could not be evaluated in this review.

\section{Methodological considerations}

The methodological quality of studies assessing manual therapies for headache disorders are frequently being criticised for being too low. Occasionally rightly so, but often do the methodological design prevent manual therapy studies from reaching what is considered gold standard in pharmacological RCTs. For instance, a placebo treatment is difficult to establish while the investigator cannot be blinded for its applied intervention. The average score of the included studies was 5.8 (SD 2.6) points and four studies were considered of good quality. All RCTs failed to include sample size $\geq 50$ in the smallest group. Sufficient sample size with power calculation prior is important to confine type 2 errors. Three studies did not state primary and secondary end-points, which confound effect-size calculation, and risk of type 2 errors inferred from multiple measures [20-22]. Conducting a manual therapy RCT is both time and cost consuming, while blinding often is difficult as there is no single validated standardized sham-treatment which can be used as a control group to this date. Thus, all of the included studies were pragmatic or used no treatment as a control group.

Apart from the participants in the retrospective study [21], all participants were diagnosed by a physician or neurologist. A diagnostic interview is the gold standard, while questionnaire and lay interviews are less precise diagnostic tools regarding headache disorders [26].

Co-intervention was only avoided in two studies [22,20]. Two studies performed intention-to-treat analysis which is recommended to protect against odd outcome values and preserve baseline comparability [24,25,27].

\section{Results}

The massage therapy study included only 11 participants, but the massage group had significantly more 
Table 3 Results of manual therapy randomized controlled trials (RCTs) of chronic tension-type headache (CTTH)

\begin{tabular}{|c|c|c|c|c|}
\hline Country & Study population & Method & Intervention & Results \\
\hline \multirow[t]{4}{*}{ Spain 2009 [20] } & 11 participants (3 M, 8 F) & $\begin{array}{l}\text { RCT of } 8 \text { days duration conducted } \\
\text { by a physiotherapist i.e. }\end{array}$ & $\begin{array}{l}\text { All interventions received two treatments } \\
\text { over } 8 \text { days lasting for } 40 \mathrm{~min}\end{array}$ & $\begin{array}{l}\text { Headache intensity decreased statistical significant } \\
24 \text { hours after massage }(p<0.05) \text {, whereas detuned } \\
\text { ultrasound had no statistical significant effect }\end{array}$ \\
\hline & Age $41-60$ yrs & $\begin{array}{l}2 \text { treatments with one week interval, } \\
\text { each followed by } 24 \text {-hours } \\
\text { post-treatment assessment }\end{array}$ & Head and neck massage & $\begin{array}{l}\text { Mean headache intensity was reduced } 24 \% \text { after } \\
\text { massage, and } 3 \% \text { after detuned ultrasound }\end{array}$ \\
\hline & Mean $51 \pm 15$ yrs & $\begin{array}{l}\text { Comparison of pre-and post-treatment } \\
\text { at the treatment laboratory }\end{array}$ & $\begin{array}{l}\text { Detuned ultrasound at head and neck } \\
\text { area (control group) }\end{array}$ & Effect size 0.32 \\
\hline & Headache diagnosed by neurologist & & Drop outs $(n=0)$ & \\
\hline \multirow[t]{6}{*}{ USA 1989 [21] } & 55 participants (15 M, $40 \mathrm{~F})$ & $\begin{array}{l}\text { RCT of } 9 \text { months duration conducted } \\
\text { by a physiotherapist i.e. } 3 \text { months } \\
\text { treatment } 3,6 \text { months follow-up }\end{array}$ & $\begin{array}{l}\text { All interventions received detoxification } \\
\text { (when necessary) and amitriptyline } \\
\text { (in some cases) }\end{array}$ & $\begin{array}{l}\text { The efficacy parameter was the mean headache } \\
\text { index defined as weekly frequency } x \text { intensity on } \\
\text { a } 0-10 \text { numeric rating. Mean headache index at } \\
\text { baseline was } 30\end{array}$ \\
\hline & Age 23-62 yrs & $\begin{array}{l}\text { Comparison of weekly treatments } \\
\text { and follow-up }\end{array}$ & Biofeedback treatment $(n=9 ; 4 M$ and $5 F)$ & $\begin{array}{l}\text { Biofeedback reduced the headache index defined } \\
\text { as frequency } x \text { intensity by } 83 \% \text { and } 76 \% \\
\text { post-treatment and } 3 \text { months follow-up, while } \\
\text { physiotherapy combined with TENS reduced it by } \\
97 \% \text { and } 93 \% \text { and TENS by } 94 \% \text { and } 92 \% \text { respectively }\end{array}$ \\
\hline & Mean age 36.9 yrs & Headache diary recordings & $\begin{array}{l}\text { Physiotherapy including heat pack, soft } \\
\text { tissue work and ultrasound with home } \\
\text { exercises and home transcutaneus } \\
\text { electrical nerve stimulation (TENS) } \\
\text { treatment, average } 12.8 \text { sessions over } \\
3 \text { months ( } \mathrm{n}=28 ; 4 \mathrm{M} \text { and } 24 \mathrm{~F} \text { ) }\end{array}$ & $\begin{array}{l}\text { The improvement was sustained at } 6 \text { months in } \\
\text { physiotherapy combined with TENS and TENS } \\
\text { group, i.e. } 95 \% \text { and } 97 \% \text { reduction of the } \\
\text { headache index }\end{array}$ \\
\hline & Mean headache duration 8.4 yrs & & $\begin{array}{l}\text { TENS treatment by physiotherapist, } 12 \\
\text { sessions followed by additional home } \\
\text { TENS treatment twice a day for another } \\
\text { month ( } n=18 ; 7 \mathrm{M} \text { and } 11 \mathrm{~F} \text { ) }\end{array}$ & \\
\hline & Retrospect headache diagnosis & & $\begin{array}{l}\text { Drop outs of } 6 \text { months follow-up } \\
(\mathrm{n}=18 ; 7 \mathrm{M} \text { and } 11 \mathrm{~F})\end{array}$ & Effect size not applicable \\
\hline & $\begin{array}{l}12 \text { participants had co-occurrence } \\
\text { of menstrual migraine }\end{array}$ & & & \\
\hline \multirow[t]{2}{*}{ Turkey 2002 [22] } & 35 female participants & $\begin{array}{l}\text { RCT of } 10 \text { weeks duration conducted } \\
\text { by a physiotherapist i.e. } 2 \text { weeks } \\
\text { baseline, } 4 \text { weeks treatment, } 4 \text { weeks } \\
\text { follow-up }\end{array}$ & $\begin{array}{l}\text { All interventions received superficial } \\
\text { heat and classic massage to the neck } \\
\text { and upper back prior to intervention }\end{array}$ & $\begin{array}{l}\text { Efficacy parameter was headache index defined } \\
\text { as headache frequency } x \text { intensity }\end{array}$ \\
\hline & Age $19-59$ yrs & $\begin{array}{l}\text { Comparison of baseline, post-treatment } \\
\text { and follow-up }\end{array}$ & $\begin{array}{l}\text { Spinal connective tissue manipulation } \\
\text { by a physiotherapist daily }(n=15)\end{array}$ & $\begin{array}{l}\text { Both the spinal connective tissue manipulation } \\
\text { and cervical mobilization groups had statistical } \\
\text { significant improvement, i.e. } 38 \% \text { vs. } 54 \% \\
\text { post-treatment and } 48 \% \text { vs. } 86 \% \text { at } 3 \text { months } \\
\text { follow-up }\end{array}$ \\
\hline
\end{tabular}

tissue work and ultrasound with home

exercises and home transcutaneus

(rectrical nerve stimulation (TENS)

3 months $(n=28.4 M$ and $24 \mathrm{~F})$

TENS treatment by physiotherapist, 12

12 participants had co-occurrence

of menstrual migraine

a physiotherapist ie. 2 weeks

heat and classic massage to the neck

as headache frequency $\mathrm{x}$ intensity

post-teant improvement, ie. $38 \%$ vs. $54 \%$

follow-up 
Table 3 Results of manual therapy randomized controlled trials (RCTs) of chronic tension-type headache (CTTH) (Continued)

\begin{tabular}{|c|c|c|c|c|}
\hline & Mean age 37.9 yrs & Headache diary recordings & $\begin{array}{l}\text { Cervical mobilization according to Cyriax } \\
\text { principle by a physiotherapist three times } \\
\text { per week }(n=15)\end{array}$ & $\begin{array}{l}\text { No statistical significant differences between } \\
\text { the two groups }\end{array}$ \\
\hline & \multicolumn{2}{|l|}{ Mean headache duration 9.8 yrs } & Drop outs $(n=5)$ & $\begin{array}{l}\text { Effect size } 0.21 \text { before to after treatment, } 0.30 \\
\text { after treatment to follow-up, and } 0.37 \text { before } \\
\text { treatment to follow-up }\end{array}$ \\
\hline & \multicolumn{4}{|l|}{ Headache diagnosed by neurologist } \\
\hline \multirow[t]{6}{*}{ Denmark 2004 [23] } & $\mathrm{CTTH}(\mathrm{n}=24)(10 \mathrm{M}, 14 \mathrm{~F})$ & $\begin{array}{l}\text { RCT of } 6 \text { months duration conducted } \\
\text { by a physiotherapist i.e. } 1 \text { month } \\
\text { baseline, } 2 \text { months treatment, } 3 \text { months } \\
\text { follow-up }\end{array}$ & $\begin{array}{l}\text { Standardised physiotherapy including } \\
\text { massage, relaxation and stretching twice } \\
\text { a week for } 4 \text { weeks followed by twice a } \\
\text { week physical group exercise for } \\
4 \text { weeks }(n=18)\end{array}$ & $\begin{array}{l}\text { Headache days were statistical significantly } \\
\text { reduced in the physiotherapy group } \\
\text { post-treatment and at follow-up as } \\
\text { compared to the observation group }(p<0.001 \text { ) }\end{array}$ \\
\hline & Age $24-63$ & $\begin{array}{l}\text { Comparison of baseline, post-treatment } \\
\text { and follow-up }\end{array}$ & $\begin{array}{l}\text { Observation period, kept diary for } 8 \text { weeks } \\
\text { followed by the same intervention }(n=19)\end{array}$ & $\begin{array}{l}54 \% \text { of participants responded with }>50 \% \\
\text { reduction of headache days }\end{array}$ \\
\hline & Mean age 44.9 yrs & Headache diary recordings & Drop outs $(n=11)(5 M, 6 F)$ & $\begin{array}{l}\text { Headache duration and intensity were } \\
\text { unchanged in both groups }\end{array}$ \\
\hline & Duration of headache $23.1 \mathrm{yrs}$ & & & $\begin{array}{l}\text { Women responded statistical significantly } \\
\text { better than men }(p=0.01)\end{array}$ \\
\hline & $\begin{array}{l}\text { Mean headache frequency } 15.8 \text { days } \\
\text { per month }\end{array}$ & & & Effect size not applicable \\
\hline & \multicolumn{4}{|l|}{ Headache diagnosed by a neurologist } \\
\hline \multirow[t]{5}{*}{ Netherland 2006 [24] } & $\begin{array}{l}\text { THH }(n=42) \text { and episodic } \\
\text { tension-type headache }(n=39)\end{array}$ & $\begin{array}{l}\text { RCT of } 7 \frac{1}{2} \text { months duration conducted } \\
\text { by twenty physiotherapist's i.e. Initial } \\
\text { baseline } 6 \text { weeks treatment, } 6 \text { months } \\
\text { follow-up, Comparison of pre- and post- } \\
\text { treatment and follow-up }\end{array}$ & $\begin{array}{l}\text { Craniocervical training program by a } \\
\text { physiotherapist including low-load } \\
\text { endurance exercises for cervicoscapular } \\
\text { and craniocervical region with twice } \\
\text { daily home exercise combined with } \\
\text { postural correction exercises }(n=39)\end{array}$ & $\begin{array}{l}\text { Both groups had statically significant } \\
\text { post-treatment improvement of headache } \\
\text { frequency, duration and intensity }\end{array}$ \\
\hline & Mean age 45.9 yrs & Headache diary recordings & $\begin{array}{l}\text { Physiotherapy including massage, } \\
\text { oscillation techniques described by } \\
\text { Maitland and postural correction }(n=40)\end{array}$ & $\begin{array}{l}\text { In the craniocervical training group } 82 \% \text { and } \\
85 \% \text { had } \geq 50 \% \text { reduction in headache frequency } \\
\text { post-treatment and at follow-up, as compared } \\
\text { to } 52 \% \text { and } 35 \% \text { in the physiotherapy group. }\end{array}$ \\
\hline & $\begin{array}{l}\text { Mean headache frequency } \\
20.7 \text { days per month }\end{array}$ & & Drop outs $(n=2)$ & $\begin{array}{l}\text { The effect was a statistical significant better in } \\
\text { those with CTTH as compared to those with } \\
\text { episodic tension-type headache ( } p<0.0001) \text {. }\end{array}$ \\
\hline & \multicolumn{3}{|l|}{ Headache diagnosed by physician } & No individual data are presented for CTTH \\
\hline & & & & Effect size not applicable \\
\hline
\end{tabular}


Table 3 Results of manual therapy randomized controlled trials (RCTs) of chronic tension-type headache (CTTH) (Continued)

\begin{tabular}{|c|c|c|c|c|}
\hline \multirow[t]{7}{*}{ Netherland 2011 [25] } & 82 participants (18 M, 64 F) & $\begin{array}{l}\text { RCT of } 8 \frac{1}{2} \text { months duration conducted } \\
\text { by four physiotherapist's i.e. } 2 \text { weeks } \\
\text { baseline, } 2 \text { months treatment, } 6 \text { months } \\
\text { follow-up }\end{array}$ & $\begin{array}{l}\text { Usual care by general practitioner which } \\
\text { consisted of information, re-assurance, } \\
\text { advise, lifestyle changes and prescription } \\
\text { of analytics and NSAIDs if necessary 2-3 } \\
\text { visits ( } n=37 \text { ) }\end{array}$ & $\begin{array}{l}\text { The manual therapy group had statistical } \\
\text { significant improvement of headache } \\
\text { frequency, duration and intensity post-treatment } \\
\text { and at follow-up as compared to usual care } \\
\text { group ( } p<0.001, p=0.003 \text {, and } p=0.013 \text { ). This } \\
\text { effect was maintained at follow-up ( } p<0.001 \\
\text { and } p=0.027 \text { ), except for duration. }\end{array}$ \\
\hline & Age $20-63$ yrs & $\begin{array}{l}\text { Comparison of baseline, post-treatment } \\
\text { and follow-up }\end{array}$ & $\begin{array}{l}\text { Manual therapy by a physiotherapist } \\
\text { consisting of mobilization of cervical and } \\
\text { thoracic column, exercises and postural } \\
\text { correction for max } 9 \text { sessions of } 30 \text { min } \\
(n=38)\end{array}$ & $\begin{array}{l}\text { At post-treatment and follow-up the headache } \\
\text { frequency was reduced } 77 \% \text { and } 77 \% \text { in the } \\
\text { manual therapy group as compared to } 23 \% \\
\text { and } 35 \% \text { in usual care group. }\end{array}$ \\
\hline & Mean age 40.4 yrs & Headache diary recordings & Drop outs $(n=7)$ & $\begin{array}{l}\text { At post-treatment and at follow-up } 88 \% \text { and } \\
82 \% \text { of the manual therapy group had }>50 \% \\
\text { reduction in headache frequency, and } 28 \% \text { and } \\
41 \% \text { of the usual care group. }\end{array}$ \\
\hline & Mean headache duration $12.8 \mathrm{yrs}$ & & & $\begin{array}{l}\text { At post-treatment and follow-up duration was } \\
\text { reduced } 46 \% \text { and } 55 \% \text { in the manual therapy } \\
\text { group as compared to } 5 \% \text { and } 27 \% \text { in the usual } \\
\text { care group. }\end{array}$ \\
\hline & $\begin{array}{l}\text { Mean headache frequency } 24 \text { days } \\
\text { per month }\end{array}$ & & & $\begin{array}{l}\text { At post-treatment and follow-up intensity was } \\
\text { reduced } 43 \% \text { and } 49 \% \text { in the manual therapy } \\
\text { group as compared to } 16 \% \text { and } 30 \% \text { in the } \\
\text { usual care group. }\end{array}$ \\
\hline & Headache diagnosed by physician & & & $\begin{array}{l}\text { Frequency, duration and intensity effect size } \\
\text { was } 0.62,0.27 \text { and } 0.44 \text { at post-treatment and } \\
0.50,0.19 \text { and } 0.26 \text { at follow-up }\end{array}$ \\
\hline & $\begin{array}{l}21 \text { participants had co-occurrence } \\
\text { of migraine }\end{array}$ & & & \\
\hline
\end{tabular}


reduction in their headache intensity than detuned ultrasound group [20].

$54 \%, 82 \%$ and $85 \%$ of the participants in three of the physiotherapy RCTs had a $\geq 50 \%$ reduction in headache frequency post-treatment [23-25], and the effect was maintained in the two studies that had a 6 months follow-up $[24,25]$. This is comparable with the $40-70 \%$ of participants whom have a similar effect using tricyclic antidepressants $[28,29]$. The effect of tricyclic also seems to improve over time, i.e. after more than 6 months treatment [29]. However, tricyclic antidepressants have a series of side effects in contrast to physiotherapy, while manual therapy requires more consultations. Two studies assessed headache index defined as headache frequency $x$ intensity $[21,22]$. Both studies showed a significant improvement post-treatment and at 1 month and 6 months follow-up respectively.

Four of the studies reported 10.1 mean years with headache, thus, the effect observed is likely to be due to the therapeutic effect rather than spontaneous improvement or regression to the mean [21-23,25].

Acute headache medication is frequently used for primary headaches, and if the headache frequency increases, there is an increased risk for medication overuse headache. Increased use of prophylactic medication has thus been suggested in the management for primary chronic headaches [3]. Since manual therapies seems to have a beneficial effect that equals the effect of prophylactic medication [28,29], without the pharmacological side effects, manual therapies should be considered on an equal level as pharmacological management strategies.

Effect size could be calculated in three of the six RCTs. Effect size on headache frequency was up to 0.62, while it was less regarding duration and intensity, while headache index (frequency $x$ intensity) was up to 0.37 (Table 3). Thus, a small to moderate effect size might however, be substantial to the individual, especially considering that nearly daily headache i.e. mean $12 / 14$ days reduced to mean $3 / 14$ days [25], which equals $\geq 75 \%$ reduction in headache frequency. Usually a $\geq 50 \%$ reduction is traditionally used in pain trails, but considering the fact that CTTH is difficult to treat, some investigators operate with $\geq 30 \%$ improvement of primary efficacy parameter compared with placebo [30].

\section{Limitations}

The present study might have possible biases. One of them being publication bias as the authors made no attempt to identify unpublished RCTs. Although we did perform a comprehensive search, we acknowledge it is possible to miss a single or few RCT, especially nonEnglish RCT.

\section{Conclusion}

Manual therapy has an efficacy in the management of CTTH that equals prophylactic medication with tricyclic antidepressant. At present no manual therapy studies exist for chronic migraine or chronic cluster headache. Future manual therapy RCTs on primary chronic headache should adhere to the recommendation of the International Headache Society, i.e. primary end point is headache frequency and secondary end-points are duration and intensity. Future manual therapy studies on $\mathrm{CM}$ with and without medication overuse is also warranted, since such studies do not exist today.

\section{Competing interests}

The authors declare that they have no competing interests.

\section{Authors' contributions}

AC prepared the initial draft and performed the methodological assessment of the included studies. MBR had the original idea of the study, planned the overall design and revised the drafted manuscript. Both authors have read and approved the final manuscript.

\section{Authors' information}

Aleksander Chaibi is a BPT, MChiro, PhD student and Michael Bjørn Russell is a professor, MD, PhD, DrMedSci.

\section{Acknowledgements}

Akershus University Hospital, Norway, kindly provided research facilities.

\section{Funding}

The study received funding from Extrastiftelsen, the Norwegian Chiropractic Association in Norway and University of Oslo.

Received: 15 August 2014 Accepted: 16 September 2014 Published: 2 October 2014

\section{References}

1. Grande RB, Aaseth K, Gulbrandsen P, Lundqvist C, Russell MB (2008) Prevalence of primary chronic headache in a population-based sample of 30- to 44-year-old persons: the Akershus study of chronic headache. Neuroepidemiology 30(2):76-83

2. Headache Classification Committee of the International Headache Society (2013) The International Classification of Headache Disorders, 3rd edition (beta version). Cephalalgia 33:629-808

3. Kristoffersen ES, Grande RB, Aaseth K, Lundqvist C, Russell MB (2012) Management of primary chronic headache in the general population: the Akershus study of chronic headache. J Headache Pain 13(2):113-120

4. Aaseth K, Grande RB, Kvaerner KJ, Gulbrandsen P, Lundqvist C, Russell MB (2008) Prevalence of secondary chronic headaches in a population-based sample of 30-44-year-old persons: the Akershus study of chronic headache. Cephalalgia 28(7):705-713

5. Bronfort G, Nilsson N, Haas M, Evans R, Goldsmith CH, Assendelft WJ, Bouter LM (2004) Non-invasive physical treatments for chronic/recurrent headache. Cochrane Database Syst Rev 3:1-69

6. Chaibi A, Tuchin PJ, Russell MB (2011) Manual therapies for migraine: a systematic review. J Headache Pain 12(2):127-133

7. Carnes D, Mars TS, Mullinger B, Froud R, Underwood M (2010) Adverse events and manual therapy: a systematic review. Man Ther 15(4):355-363

8. Lenssinck ML, Damen L, Verhagen AP, Berger MY, Passchier J, Koes BW (2004) The effectiveness of physiotherapy and manipulation in patients with tension-type headache: a systematic review. Pain 112(3):381-388, doi:10.1016/j.pain.2004.09.026

9. Fernandez-de-Las-Penas C, Alonso-Blanco C, Cuadrado ML, Miangolarra JC, Barriga FJ, Pareja JA (2006) Are manual therapies effective in reducing pain from tension-type headache: a systematic review. Clin J Pain 22(3):278-285, doi:10.1097/01.ajp.0000173017.64741.86

10. Chaibi A, Russell MB (2012) Manual therapies for cervicogenic headache: a systematic review. J Headache Pain 13(5):351-359 
11. Posadzki P, Ernst E (2012) Spinal manipulations for tension-type headaches: a systematic review of randomized controlled trials. Complement Ther Med 20(4):232-239, doi:10.1016/j.ctim.2011.12.001

12. French HP, Brennan A, White B, Cusack T (2011) Manual therapy for osteoarthritis of the hip or knee - a systematic review. Man Ther 16(2):109-117, doi:10.1016/.math.2010.10.011

13. Tfelt-Hansen P, Block G, Dahlof C, Diener HC, Ferrari MD, Goadsby PJ, Guidetti V, Jones B, Lipton RB, Massiou H, Meinert C, Sandrini G, Steiner T, Winter PB, International Headache Society Clinical Trial Subcommittee (2000) Guidelines for controlled trials of drugs in migraine: second edition. Cephalalgia 20(9):765-786

14. Silberstein S, Tfelt-Hansen P, Dodick DW, Limmroth V, Lipton RB, Pascual J, Wang SJ, Task Force of the International Headache Society Clinical Trial Subcommittee (2008) Guidelines for controlled trials of prophylactic treatment of chronic migraine in adults. Cephalalgia 28(5):484-495

15. Headache Classification Committee of the International Headache Society (1988) Classification and diagnostic criteria for headache disorders, cranial neuralgias and facial pain: Headache Classification Committee of the International Headache Society. Cephalalgia 8(suppl 7):1-96

16. Headache Classification Subcommittee of the International Society (2004) The international classification of headache disorders: 2 nd edition. Cephalalgia 24(Suppl 1):9-160

17. Olesen J, Bousser MG, Diener HC, Dodick D, First M, Goadsby PJ, Gobel H, Lainez MJ, Lance JW, Lipton RB, Nappi G, Sakai F, Schoenen J, Silberstein SD, Steiner TJ (2006) International Headache Society New appendix criteria open for a broader concept of chronic migraine. Cephalalgia 26(6):742-746

18. Moseley AM, Herbert RD, Sherrington C, Maher CG (2002) Evidence for physiotherapy practice: a survey of the Physiotherapy Evidence Database (PEDro). Aust J Physiother 48(1):43-49

19. Cohen J (1988) Statistical Power Analysis for the Behavioral Sciences, 2nd edn. Routledge, USA

20. Toro-Velasco C, Arroyo-Morales M, Fernandez-de-las-Penas C, Cleland JA, Barrero-Hernandez FJ (2009) Short-term effects of manual therapy on heart rate variability, mood state, and pressure pain sensitivity in patients with chronic tension-type headache: a pilot study. J Manipulative Physiol Ther 32(7):527-535

21. Jay GW, Brunson J, Branson SJ (1989) The effectiveness of physical therapy in the treatment of chronic daily headaches. Headache 29(3):156-162

22. Demirturk F, Akarcali I, Akbayrak T, Citak I, Inan L (2002) Results of two different manual therapy techniques in chronic tension-type headache. Pain Clin 14(2):121-128

23. Torelli P, Jensen R, Olesen J (2004) Physiotherapy for tension-type headache: a controlled study. Cephalalgia 24(1):29-36

24. Ettekoven VH, Lucas C (2006) Efficacy of physiotherapy including a craniocervical training programme for tension-type headache; a randomized clinical trial. Cephalalgia 26(8):983-991

25. Castien RF, Van der Windt DA, Grooten A, Dekker J (2011) Effectiveness of manual therapy for chronic tension-type headache: a pragmatic, randomised, clinical trial. Cephalalgia 31(2):133-143

26. Rasmussen BK, Jensen R, Olesen J (1991) Questionnaire versus clinical interview in the diagnosis of headache. Headache 31(5):290-295

27. Moher D, Hopewell S, Schulz KF, Montori V, Gotzsche PC, Devereaux PJ, Elbourne D, Egger M, Altman DG (2010) CONSORT 2010 explanation and elaboration: updated guidelines for reporting parallel group randomised trials. BMJ 340:C869

28. Bendtsen L, Jensen R, Olesen J (1996) A non-selective (amitriptyline), but not a selective (citalopram), serotonin reuptake inhibitor is effective in the prophylactic treatment of chronic tension-type headache. J Neurol Neurosurg Psychiatry 61(3):285-290

29. Jackson JL, Shimeall W, Sessums L, Dezee KJ, Becher D, Diemer M, Berbano E, O'Malley PG (2010) Tricyclic antidepressants and headaches: systematic review and meta-analysis. BMJ 341:c5222

30. Bendtsen L, Bigal ME, Cerbo R, Diener HC, Holroyd K, Lampl C, Mitsikostas DD, Steiner TJ, Tfelt-Hansen P (2010) Guidelines for controlled trials of drugs in tension-type headache: second edition. Cephalalgia 30(1):1-16

doi:10.1186/1129-2377-15-67

Cite this article as: Chaibi and Russell: Manual therapies for primary chronic headaches: a systematic review of randomized controlled trials. The Journal of Headache and Pain 2014 15:67.

\section{Submit your manuscript to a SpringerOpen ${ }^{\circ}$ journal and benefit from:}

- Convenient online submission

- Rigorous peer review

- Immediate publication on acceptance

- Open access: articles freely available online

- High visibility within the field

- Retaining the copyright to your article

Submit your next manuscript at $\gg$ springeropen.com 